\title{
Trade Competitiveness of Indian Wheat during Post-Reform Period
}

\author{
Sonu Madan ${ }^{1}$ and Rajni Sharma ${ }^{2}$ \\ ${ }^{1}$ Assistant Professor, Department of Economics, Indira Gandhi University, Meerpur, Rewari, Haryana, India \\ ${ }^{2}$ Assistant Professor, Department of Economics, Arya P.G. College, Panipat, Haryana, India \\ E-Mail: sonumadan15@gmail.com, sharma4rajni_2008@rediffmail.com
}

\begin{abstract}
The present study analyses trade competitiveness of wheat export of India for the time period 1991 to 2016 using Nominal Protection Coefficient (NPC), temporal behaviour of NPC and Constant Market Share Analysis. The results revealed that Indian wheat has not been competitive in a regular manner under both exportable and importable hypothesis. Indian wheat has been found to be competitive under importable and exportable hypothesis during the period 1991-92 to 2000-01 \& during 2011-12 to 2015-2016, but not competitive during 2001-02 to 2010-11. Constant Market Share Analysis suggests that export growth of wheat is attributed only to world trade effect or growth in the size of world trade and market distribution effect or concentration of Indian wheat exports in the market, which are relatively growing. So far as, export competitiveness of Indian wheat is concerned, the analysis reveals that there is competitive disadvantage in the wheat exports as compared to rest of world.

Keywords: Trade Competitiveness, Indian Wheat, Nominal Protection Coefficient, Competitive Advantage
\end{abstract}

\section{INTRODUCTION}

Wheat is a very important crop and a consumption source for the majority of people in India. The wheat grown in India is primarily hard or durum type wheat. It has a high protein content that is largely soft, medium hard, medium protein, white bread wheat somewhat similar to U.S. hard white wheat. Policies on export of agricultural products have seen frequent changes to protect the interest of domestic consumers and industries. The implications of such ambivalent trade policies have to be carefully considered in view of the legitimate interest of the Indian farmers \& our commitment to international organization like the world Trade Organization (WTO). Despite policy uncertainties, over the years, India has developed export competitiveness for certain specialized products like wheat. This paper is an attempt to measure the export competitiveness of Indian wheat and designs major strategies for its enhancement. The difference between the concept of comparative advantage and competitive advantage highlights the significance of trade competitiveness. The concept of comparative advantage is widely used to evaluate pattern of trade \& is based on the concept of opportunity cost and relative efficiency commodities across countries. On the other hand, competitiveness is a statement about differences in market prices (Dunmore, 2008). While relative prices among competitors define the level of exports and market share, it is competitiveness that makes good cheaper in one country than other. A crux here is that comparative advantage is a statement about what trade patterns "ought to be" competitiveness is a statement about trade patterns.

\section{LITERATURE REVIEW AND HYPOTHESIS FORMATION}

\section{A. Trade Supporting Policies and Export Competitiveness}

Economic reforms initiated in India in 1991 include a sharp devaluation of Indian rupee which made many Indian agricultural products competitive in the world market. But the scenario changed after Asian Crisis of 1996 that brought a slowdown in Indian agricultural trade and its growth. (Bhalla, 2004). Further, Gulsia et al. 2008 analyzed the impact of GATT 1994 on agriculture in India to study the competitiveness of Indian wheat in the international market by comparing the cost of Indian wheat Ex- Kandla port and U.S. port for the period 1991-92 to 1998-99. The Indian wheat was even internationally competitive in the year 1995-96 when wheat price was US\$ 216 per ton. In the same line, Ohlan, 2008 attempted to measure the impact of WTO on Indian agriculture \& analyzed the competitiveness of Indian major crops for the time period 1994-95 to 200304 and brought out the fact that the competitiveness of Indian agriculture declined under exportable and importable hypothesis. Since 2008, India faced with a surplus of wheat due to excess domestic production which was due to domestic support policies that restrict India's world trade (National Trade Report, 2014). Hereby, we would expect that trade supporting policies \& WTO provisions in this regards during economic have not been much supportive to enhance competitiveness of Indian wheat under exportable and importable hypothesis.

$H_{0} 1$ : Trade supporting policies under economic reforms does not lead to enhancement of export competitiveness of Indian wheat

\section{B. Regional Dispersion of Competitiveness}

Indian agricultural price policy has been biased in favor of wheat and rice and also in favor of northern states of Punjab \& Haryana revealing out the fact that Indian agricultural price policy has been a major cause of regional dispersion of competitiveness of Indian wheat, among others (Gulati $e t$ al. 1990; Pursell \& Gupta, 1997). Over the time period, a comparative state-level analysis shows that major rice 
producing states are efficient producers of rice but among major producing states of wheat, only Punjab, Haryana and UP are efficient, so far as competitiveness of Indian wheat is concerned (Bhalla, 2004). NPC for maize has been calculated for major producing states in India. The results revealed that NPC was less than unity for major maize producing states except Bihar and Uttar Pradesh for some years (Ohlan, 2008). A study of (Bhalla \& Singh 1996) brings out the result that Punjab is internationally competitive in the export of rice and cotton to the rest of the world.

$\mathrm{H}_{0}$ 2: $\quad$ There are regional variations in the trade Competitiveness of Indian wheat.

\section{Global Export Growth and Domestic Export Competitiveness}

India's competitiveness of manufactured exports has been analyzed using constant market share analysis (CMS) where total export effect was decomposed into world trade effect, commodity composition effect, market distribution effect and competitiveness effect for the time period 1980-2005. Constant market share analysis is a popular method to measure the increased competitiveness and an analysis to relate changes in a competitive condition due to trade liberalization (Ichikawa, 1996). The study revealed that for all time periods, world trade effect was found to be favorable for all manufacturing sectors. The competitiveness effect indicates an improved position of exports in terms of competitiveness (Kaur, 2009). The CMS Analysis shows that Austrian trade was able to keep its market share in the open global environment. Further, the competitiveness effect is positive whereas market and product structure effect shows negative trends after 2000, pointing towards the vulnerability in the Austrian export sector (Skriner, 2009). Given this, it seems reasonable to propose that there is some correlation between world export growth, world wheat export growth and other international factors and India's export growth that create its impact on export competitiveness of wheat in India.

$H_{0} 3$ : Export competitiveness of Indian wheat is influenced by world exports growth.

\section{RESEARCH METHODOLOGY}

\section{A. Data Base and Selection of Variables}

The study has been conducted on Export Competitiveness of India for the time period of 1991-2016. Punjab, Haryana, Uttar Pradesh, Madhya Pradesh and Rajasthan are the major wheat producing states and hereby are selected for the study. Delhi is the famous agro food processing market in India that has also been selected for calculating NPC under the study. Various secondary data sources have been utilized to capture information leading to fulfillment of objectives of the study. HS Code 1001 data has been collected for wheat exports and imports. Annual Data on Domestic wholesale prices of mentioned five states and Union Territory namely Delhi is obtained from Commission on Agriculture Cost \& Prices. Data on international prices, Unit value of export \& Import, world exports, wheat exports of different countries has been collected from Food \& Agriculture organization, APEDA and UNCOMTRADE respectively. Domestic transport cost data has collected from Annual reports and Accounts of Indian Railway which was further adjusted for Rail and Road transport charges following the methodology given by Gulati et al. (1990), "Effective Incentives in India's Agriculture". Variables are selected purposefully to arrive at desired results.

TABLE I VARIABLES AND PURPOSES

\begin{tabular}{|l|l|}
\hline \multicolumn{1}{|c|}{ Variables } & \multicolumn{1}{c|}{ Purpose } \\
\hline $\begin{array}{l}\text { Domestic Prices(Wheat)/ International } \\
\text { Prices(Wheat)/ Domestic Transport Cost, } \\
\text { Unit Export Price, Unit Import Price }\end{array}$ & $\begin{array}{l}\text { Used to measure } \\
\text { Nominal } \\
\text { Protection } \\
\text { Coefficient }\end{array}$ \\
\hline $\begin{array}{l}\text { Total World Exports, World Wheat } \\
\text { Exports, India 's Wheat Exports, India's } \\
\text { Wheat Exports to Selected Destinations }\end{array}$ & $\begin{array}{l}\text { Used to conduct } \\
\text { Constant Market } \\
\text { Share Analysis }\end{array}$ \\
\hline
\end{tabular}

\section{B. Techniques and Model Specification}

\section{Nominal Protection Coefficient (NPC)}

NPC is defined as the ratio of domestic price to international price. The domestic price used in this computation is procurement/ wholesale price while the world reference price is the international prices adjusted for transport costs, marketing costs and processing cost necessary to make the commodity comparable.

$N P C_{i}=\frac{P_{i}^{d}}{P_{i}^{w}}$

Here,

$N P C_{i}$ - Nominal protection coefficient of commodity I

$P_{i}^{d} \quad$ - Domestic price of commodity $i$

$P_{i}^{W}$ - World reference price of commodity $i$, adjusted for transportation, handling and marketing expenses.

The estimated NPC of a crop $<1$ indicates that the crop is competitive and vice-versa.

\section{Constant Market Share Analysis}

Constant Market Share Analysis is a popular method used by Tyszynski (1951) in a prominent work in applied international economics. The CMS analysis assumes that the focus country's share in the world market is constant over the time.

The CMS, numerically can be expressed as: $\mathrm{Xi}^{1} \mathrm{Xi}^{0}$ $\left[\sum_{i=1}^{n} r . X i\right]$

$\Delta X=$

$\left[\sum_{i=1}^{n} r . X i\right]+\left[\sum_{i=1}^{n}(r i X i-r X i)\right]+\left[\sum_{i=1}^{n} \sum_{j=1}^{m} r i j X i j-\right.$ $\left.\sum_{i=1}^{n} r . X i\right]+\left[\sum_{i=1}^{n} \quad(\mathrm{Xi} 1-\mathrm{Xi} 0)-\sum_{i=1}^{n} \sum_{j=1}^{m} r i j X i j\right]$

Here $1=$ terminal year

$0=$ Base year or Initial time period

$1=1,2,3$------------n number of Commodities 
Xi1 $=$ Total exports of commodity $\mathrm{i}$ by the focus country (India) in the base year

Xil $=$ Total exports of commodity i by the focus country (India) in the terminal year

$\mathrm{Xij}^{0}=$ Total exports by India for the ith commodity to the $\mathrm{jth}$ market in the terminal year.

$r=$ Percentage change (from base year to terminal year) in total world exports.

$r_{i}=$ Percentage change ( from base year to terminal year) in total world exports of the ith commodity.

$\mathrm{r}_{\mathrm{ij}}=$ Percentage change (from base year to terminal year) in total world exports of the ith commodity to the jth market.

\section{CMS Model Specification}

The model decomposes export growth of India in four components

1) World trade Effect (WTE) $=\left[\sum_{i=1}^{n} r . X i\right]$-World trade effect measures the growth/decline in focus country's export due to general growth or decline in world exports. A positive/negative value of WTE indicates an increase/decrease in focus country's exports due to general rise/fall in world demand given a constant market share of the focus country.

2) Commodity Composition Effect (CCE) $\left[\sum_{i=1}^{n}(r i X i-\right.$ $r X i)]$ - A positive CCE indicates that an increase in exports of a focus country is more than the world exports of a similar commodity. It implies that focus country's exports are concentrated for those commodities whose demand is increasing at a higher rate than aggregate growth rate (r) of the total world exports. A negative CCE value indicates the inverse situation.

3) Market Distribution effect (MDE) = $\left[\sum_{i=1}^{n} \sum_{j=1}^{m} r i j X i j-\sum_{i=1}^{n} r . X i\right]$ - This effect stems from the geographical distribution of the reference country's exports. A positive value of market distribution effect

4) indicates that a reference country's exports are directed to relatively growing markets. A negative value indicates that the exports of the reference country are concentrated in markets where demand is growing slowly than the rest of the world.

5) Competitiveness Effect $(\mathrm{CE})=\left[\sum_{i=1}^{n} \quad(\mathrm{Xi1}-\mathrm{Xi} 0)-\right.$ $\left.\sum_{i=1}^{n} \sum_{j=1}^{m} r i j X i j\right]$ - This effect reveals the capacity of a country to achieve a rise in its market share in the world market due to competitive factors only. A positive/ negative value of competitiveness effect reflects a competitive advantage/disadvantage of the focus country of a particular commodity compared to the rest of world.

\section{RESULTS AND DISCUSSION}

Trade competitiveness relies on the statement of differences in market prices. Export competitiveness of a commodity depends mainly on the wedge between international and domestic prices. The study assumed domestic prices as Delhi's Wholesale Average prices and International prices, as US No. $2 \mathrm{HRW}$ wheat prices. If the domestic prices of Indian wheat are less than the international prices only then it is export competitive, otherwise not. Interestingly, wheat is occasionally exported from India. Fig. 1 presents the comparison of domestic price and international price of Indian wheat. During the initial years of economic reforms, wheat exports are attributed to low domestic wholesale prices compared to international prices. For later years, from 1997 to 2010, domestic prices remain well above the international prices that make Indian exports less competitive. It is only in 2011, when international prices started rising due to Russia's ban on wheat exports and other international factors that contributed to make Indian wheat competitive in the world market. International price volatility caused to makes Indian wheat less competitive in 2014 when international prices again declined and domestic prices of India wheat became less competitive with international prices in further years. The comparison of domestic prices and international prices depicted in the chart reveals that India is not competitive in wheat exports in a regular manner.

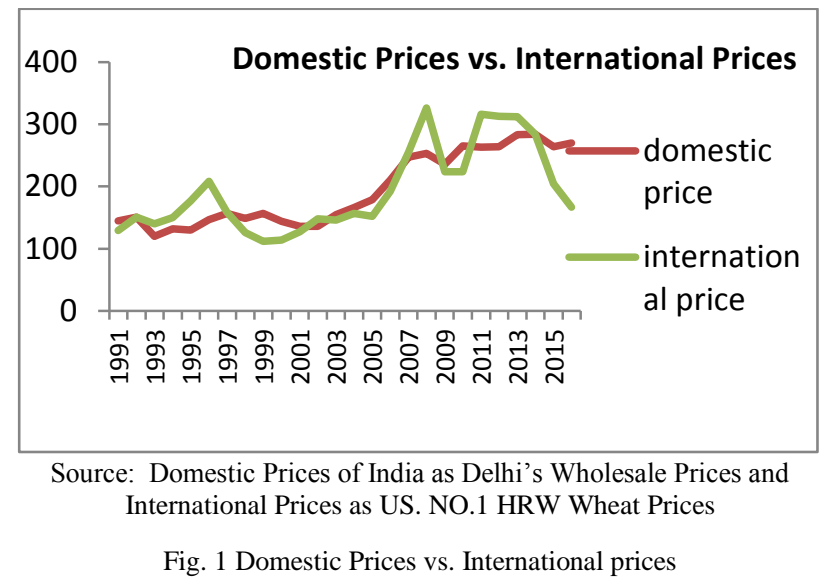

A. Trade Supporting Policies under Economic Reforms and Export Competitiveness of Indian Wheat

Under exportable hypothesis, there is no export competitiveness in the initial two years. Then in the early period of 1990s from 1993-94 to 1999-00, wheat is export competitive as its NPC value is less than one for all six states. It indicates that all states are efficient producer of wheat and can compete efficiently in world market for wheat exports. But eventually, it become non-competitive as NPC value is more than one from 2000-01 to 2006-07. The main reason for declining competitiveness was a very heavy fall in prices of wheat in the international market. During the period 2007-8 to 2014-15, India again turned out to be export competitive in the world market. The recent scenario of Indian wheat is non-competitive in wheat exports in 2015-16 \& 2016-17 with more than one NPC value for all six states. 
TABLE II NOMINAL PROTECTION COEFFICIENT (EXPORTABLE HYPOTHESIS)

\begin{tabular}{|c|c|c|c|c|c|c|c|}
\hline Year & $\begin{array}{c}\text { Punjab } \\
\text { (Ludhiana) }\end{array}$ & $\begin{array}{l}\text { Haryana } \\
\text { (Karnal) }\end{array}$ & $\begin{array}{c}\text { UP } \\
\text { (Hapur) }\end{array}$ & $\begin{array}{c}\text { MP } \\
\text { (Indore) }\end{array}$ & $\begin{array}{c}\text { Rajasthan } \\
\text { (Jaipur) }\end{array}$ & Delhi & Average \\
\hline $1991-92$ & 1.29 & 1.28 & 1.42 & 1.60 & 1.25 & 1.45 & 1.38 \\
\hline $1992-93$ & 1.18 & 1.18 & 1.21 & 1.65 & 1.22 & 1.31 & 1.29 \\
\hline 1993-94 & 0.68 & 0.68 & 0.71 & 0.85 & 0.65 & 0.73 & 0.72 \\
\hline $1994-95$ & 0.74 & 0.76 & 0.83 & 0.97 & 0.84 & 0.85 & 0.83 \\
\hline $1995-96$ & 0.65 & 0.66 & 0.70 & 0.84 & 0.72 & 0.75 & 0.72 \\
\hline $1996-97$ & 0.85 & 0.88 & 1.12 & 1.15 & 0.95 & 0.96 & 0.98 \\
\hline $1997-98$ & 0.90 & 0.90 & 0.91 & 0.89 & 0.88 & 0.92 & 0.90 \\
\hline 1998-99 & 0.75 & 0.76 & 0.78 & 0.95 & 0.84 & 0.82 & 0.82 \\
\hline 1999-00 & 0.73 & 0.75 & 0.77 & 0.82 & 0.79 & 0.76 & 0.71 \\
\hline $2000-01$ & 1.11 & 0.67 & 1.14 & 1.41 & 1.16 & 1.24 & 1.12 \\
\hline 2001-02 & 1.20 & 1.12 & 1.22 & 1.51 & 1.16 & 1.28 & 1.25 \\
\hline $2002-03$ & 1.25 & 1.28 & 1.33 & 1.72 & 1.34 & 1.41 & 1.39 \\
\hline 2003-04 & 1.67 & 1.42 & 1.64 & 1.34 & 1.13 & 1.26 & 1.41 \\
\hline 2004-05 & 0.95 & 1.16 & 1.35 & 1.11 & 0.96 & 1.05 & 1.10 \\
\hline $2005-06$ & 0.96 & 0.88 & 1.41 & 1.00 & 1.01 & 1.10 & 1.06 \\
\hline 2006-07 & 1.52 & 1.15 & 1.57 & 1.32 & 1.21 & 1.32 & 1.34 \\
\hline $2007-08$ & 0.92 & 0.98 & 0.97 & 1.04 & 0.89 & 1.04 & 0.97 \\
\hline 2008-09 & 0.78 & 0.83 & 0.81 & 1.11 & 0.79 & 0.84 & 0.86 \\
\hline 2009-10 & 1.02 & 0.97 & 1.01 & 1.34 & 1.14 & 0.99 & 1.08 \\
\hline 2010-11 & 0.70 & 0.66 & 0.68 & 0.82 & 0.78 & 0.70 & 0.72 \\
\hline 2011-12 & 0.94 & 0.84 & 0.83 & 1.17 & 0.95 & 0.89 & 0.94 \\
\hline $2012-13$ & 0.83 & 0.84 & 0.84 & 0.90 & 0.98 & 0.93 & 0.89 \\
\hline 2013-14 & 0.88 & 0.87 & 0.90 & 0.98 & 1.04 & 0.96 & 0.94 \\
\hline 2014-15 & 0.90 & 0.82 & 0.88 & 0.95 & 1.01 & 0.92 & 0.91 \\
\hline $2015-16$ & 0.99 & 0.98 & 0.98 & 0.99 & 1.13 & 0.96 & 1.01 \\
\hline $2016-17$ & 1.03 & 1.05 & 0.99 & 1.02 & 1.04 & 1.05 & 1.03 \\
\hline
\end{tabular}

Under importable hypothesis, NPC value less than one indicates that wheat is competitive in the world market and an efficient import substitute for wheat imports that gives protection to the domestic wheat producers. Economic reforms started in 1991 contributed towards making Indian wheat import competitive in the world market. In the initial years of 1990s from 1991-92 to 1997-98, NPC value of India's wheat production has been less than one which indicates that wheat is import competitive. It reflects that all states are efficient cultivators of wheat and can efficiently compete with the imports of wheat under free trade. But with the agreement on agriculture taken place in 1998-99, NPC under the importable hypothesis becomes more than one that revealing Indian wheat as non-competitive crop. In Table III, NPC is more than one from 1998-99 to 2007-08 for all states reflecting inefficiency of all states in wheat production and domestic policies to support competitive position of India in the world market. The year 2008-09 onwards, NPC value under importable hypothesis was approximately less than one for all states reflecting its attainment of earlier position of competitiveness. But like exportable hypothesis, wheat crop was again found to be import competitive in the recent years.

\section{B. Temporal Behavior of Nominal Protection Coefficient for Wheat}

The wheat specific NPCs are also calculated as weighted average of the state NPCs. Table IV presents the temporal behavior of NPCs of wheat under both the hypotheses. Nominal protection coefficient for wheat under exportable as well as importable hypothesis is more than unity when weighted average NPCs are calculated during the period 1991-2016. A long run time series analysis of NPCs reflects that wheat is a non-competitive crop as an export commodity (i.e. $\mathrm{NPC}=1.01$ ) and as an import substitutes $(\mathrm{NPC}=1.02)$. The result shows that wheat is not an efficient exportable commodity and not an efficient import substitute commodity which proves the non-competitiveness of wheat crop for traded it in the world market. But if study analyses the sub period results the story is little bit different. 
TABLE III NPC (IMPORTABLE HYPOTHESIS)

\begin{tabular}{|c|c|c|c|c|c|c|c|}
\hline Year & $\begin{array}{c}\text { Punjab } \\
\text { (Ludhiana) }\end{array}$ & $\begin{array}{l}\text { Haryana } \\
\text { (Karnal) }\end{array}$ & $\begin{array}{c}\text { UP } \\
\text { (Hapur) }\end{array}$ & $\begin{array}{c}\text { MP } \\
\text { (Indore) }\end{array}$ & $\begin{array}{c}\text { Rajasthan } \\
\text { (Jaipur) }\end{array}$ & Delhi & Average \\
\hline $1991-92$ & 0.78 & 0.77 & 0.86 & 0.96 & 0.75 & 0.88 & 0.83 \\
\hline $1992-93$ & 0.70 & 0.70 & 0.72 & 0.99 & 0.73 & 0.78 & 0.77 \\
\hline $1993-94$ & 0.80 & 0.81 & 0.84 & 1.00 & 0.77 & 0.86 & 0.85 \\
\hline 1994-95 & 0.56 & 0.58 & 0.63 & 0.74 & 0.64 & 0.64 & 0.63 \\
\hline $1995-96$ & 0.33 & 0.33 & 0.35 & 0.42 & 0.36 & 0.37 & 0.36 \\
\hline $1996-97$ & 0.89 & 0.93 & 0.98 & 1.21 & 0.99 & 1.02 & 1.00 \\
\hline $1997-98$ & 0.88 & 0.89 & 0.88 & 1.15 & 0.98 & 0.94 & 0.96 \\
\hline 1998-99 & 1.06 & 1.07 & 1.10 & 1.34 & 1.19 & 1.16 & 1.16 \\
\hline 1999-00 & 1.28 & 1.31 & 1.35 & 1.44 & 1.37 & 1.32 & 1.35 \\
\hline $2000-01$ & 0.88 & 0.89 & 0.88 & 1.15 & 0.98 & 0.94 & 0.90 \\
\hline 2001-02 & 1.14 & 1.07 & 1.15 & 1.43 & 1.11 & 1.21 & 1.19 \\
\hline $2002-03$ & 0.94 & 0.96 & 1.00 & 1.29 & 1.01 & 1.06 & 1.05 \\
\hline 2003-04 & 1.15 & 1.15 & 1.61 & 1.32 & 1.11 & 1.24 & 1.26 \\
\hline 2004-05 & 1.60 & 1.61 & 2.28 & 1.88 & 1.63 & 1.78 & 1.79 \\
\hline $2005-06$ & 1.24 & 1.13 & 1.81 & 1.29 & 1.30 & 1.41 & 1.36 \\
\hline 2006-07 & 1.02 & 1.02 & 1.39 & 1.16 & 1.07 & 1.16 & 1.14 \\
\hline 2007-08 & 1.03 & 1.09 & 1.08 & 1.15 & 1.00 & 1.16 & 1.08 \\
\hline 2008-09 & 0.70 & 0.75 & 0.73 & 0.99 & 0.71 & 0.75 & 0.77 \\
\hline $2009-10$ & 0.97 & 0.93 & 0.96 & 1.28 & 1.09 & 0.95 & 1.03 \\
\hline $2010-11$ & 0.94 & 0.88 & 0.91 & 1.10 & 1.05 & 0.95 & 0.97 \\
\hline 2011-12 & 1.09 & 0.98 & 0.97 & 1.36 & 1.10 & 1.03 & 1.09 \\
\hline 2012-13 & 0.83 & 0.84 & 0.84 & 0.91 & 0.98 & 0.93 & 0.89 \\
\hline 2013-14 & 0.68 & 0.67 & 0.69 & 0.75 & 0.79 & 0.73 & 0.72 \\
\hline $2014-15$ & 0.82 & 0.75 & 0.81 & 0.86 & 0.92 & 0.84 & 0.83 \\
\hline $2015-16$ & 1.11 & 1.12 & 1.11 & 1.11 & 1.27 & 1.08 & 1.13 \\
\hline 2016-17 & 1.48 & 1.52 & 1.43 & 1.48 & 1.48 & 1.48 & 1.48 \\
\hline
\end{tabular}

During the time period 1991-92 to 2000-01 NPCs value for exportable and importable hypothesis was less than unity i.e., 0.95 and 0.88 respectively which reveals Indian wheat competitive under exportable as well as importable hypothesis. As wheat crop always shows fluctuations in wheat trade, it is also reflected here in its competitiveness. During the period 2001-02 to 2010-2011 weighted average NPC value under both hypothesis was found to be more than unity i.e. $\mathrm{NPC}=1.12$ under exportable hypothesis and $\mathrm{NPC}=1.16$ under importable hypothesis that rendering the wheat crop uncompetitive in world market. It indicates that under exportable hypothesis domestic wholesale price of wheat is 12 percent [(NPC-1)100] higher than export price of Indian wheat. It reflects that Indian wheat is highly protected and non-competitive hence for private traders, it is not profitable to go for export of wheat. NPCs under importable hypothesis reflect an upward trend, hence, indicating non-competitiveness of temporal behavior of wheat (Fig 2). It is to be noted here that higher domestic wholesale prices than import prices make India noncompetitive under importable hypothesis. The non- competitive behavior of wheat crop under exportable and importable hypothesis suggests that wheat is neither have been an efficient exportable commodity nor an efficient import substitute commodity during the period 2001-02 to 2010-11. A direct policy implication can be drawn for policy makers to allocate resources in such a way that expand wheat production to the point, where it can act as an import substitute. But during the period 2011-12 to 201617 , wheat NPCs was less than unity $(\mathrm{NPC}=0.95)$ under exportable hypothesis and greater than unity (1.02) under importable hypothesis. During 1991-92 to 2016-17, NPCs witnessed fluctuations with downward trend, indicating increasing competitiveness of Indian wheat in the international market (Fig. 2). These results suggest that wheat has a potential to be export competitive in the recent scenario hence resource allocation would be directed to expand production of wheat to the point they can be exported and therefore maintain a growth rate that equals more than domestic demand. In general, the null hypothesis of competitiveness of wheat under exportable hypothesis for all period has been rejected and indicates that economic 
reforms lead to enhance wheat exports and its competitiveness to some extent but not in a regular manner.
At the same time, we fail to reject the null hypothesis that wheat is not competitive under importable hypothesis.

TABLE IV TEMPORAL BEHAVIOR OF NOMINAL PROTECTION COEFFICIENT FOR WHEAT (STATE AVERAGE)

\begin{tabular}{|c|c|c|c|c|c|c|c|c|}
\hline Year & NPCs & NPCs & Year & NPCs & NPCs & Year & NPCs & NPCs \\
\hline & $\begin{array}{l}\text { Exportable } \\
\text { Hypothesis }\end{array}$ & $\begin{array}{l}\text { Importable } \\
\text { Hypothesis }\end{array}$ & & $\begin{array}{l}\text { Exportable } \\
\text { Hypothesis } \\
\end{array}$ & $\begin{array}{l}\text { Importable } \\
\text { Hypothesis }\end{array}$ & & $\begin{array}{l}\text { Exportable } \\
\text { Hypothesis }\end{array}$ & $\begin{array}{l}\text { Importable } \\
\text { Hypothesis }\end{array}$ \\
\hline 1991-92 & 1.38 & 0.83 & 2001-02 & 1.25 & 1.19 & 2011-12 & 0.94 & 1.09 \\
\hline $1992-93$ & 1.29 & 0.77 & $2002-03$ & 1.39 & 1.05 & $2012-13$ & 0.89 & 0.89 \\
\hline 1993-94 & 0.72 & 0.85 & 2003-04 & 1.41 & 1.26 & 2013-14 & 0.94 & 0.72 \\
\hline $1994-95$ & 0.83 & 0.63 & 2004-05 & 1.1 & 1.79 & 2014-15 & 0.91 & 0.83 \\
\hline $1995-96$ & 0.72 & 0.36 & 2005-06 & 1.06 & 1.36 & $2015-16$ & 1.01 & 1.13 \\
\hline $1996-97$ & 0.98 & 1.00 & 2006-07 & 1.34 & 1.14 & 2016-17 & 1.03 & 1.48 \\
\hline $1997-98$ & 0.90 & 0.96 & 2007-08 & 0.97 & 1.08 & $\begin{array}{l}\text { Weighted } \\
\text { Average } \\
(2011-12 \text { to } \\
2016-17) \\
\end{array}$ & 0.95 & 1.02 \\
\hline $1998-99$ & 0.82 & 1.16 & 2008-09 & 0.86 & 0.77 & & & \\
\hline 1999-00 & 0.71 & 1.35 & 2009-10 & 1.08 & 1.03 & & & \\
\hline $2000-01$ & 1.12 & 0.90 & 2010-11 & 0.72 & 0.97 & & & \\
\hline $\begin{array}{l}\text { Weighted } \\
\text { Average } \\
(1991-92 \text { to } \\
2000-01)\end{array}$ & 0.95 & 0.88 & $\begin{array}{l}\text { Weighted } \\
\text { Average } \\
\text { (2001-02 } \\
\text { to } 2010- \\
11)\end{array}$ & 1.12 & 1.16 & $\begin{array}{l}\text { Weighted } \\
\text { Average } \\
(1991-92 \text { to } \\
2016-17)\end{array}$ & 1.01 & 1.02 \\
\hline
\end{tabular}

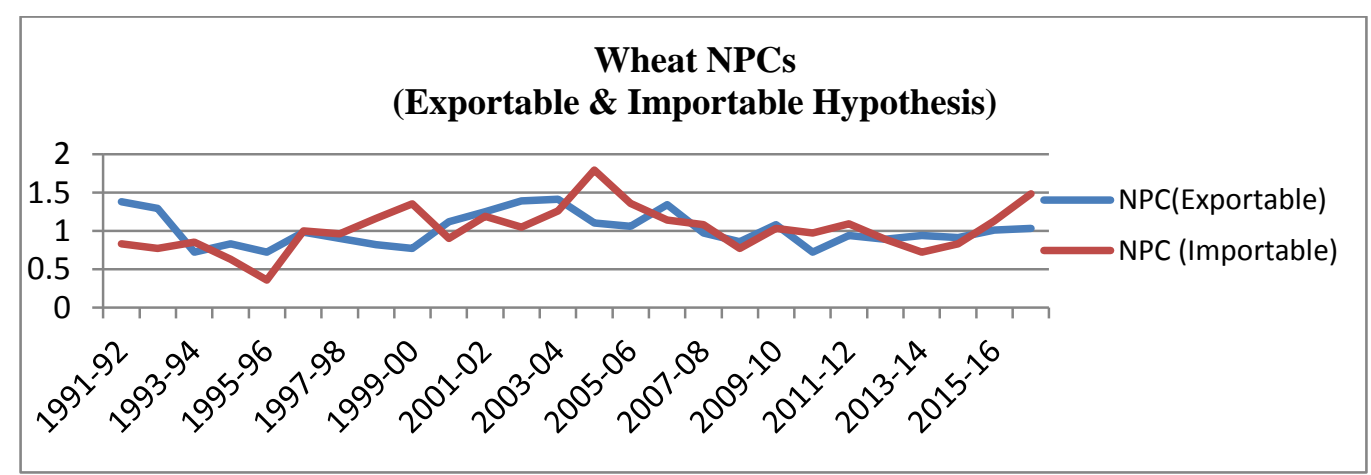

Fig. 2 Temporal Behaviour of NPC of Wheat (Exportable Hypothesis)

\section{Regional Variation of Nominal Protection Coefficient for Wheat}

NPCs, across the states, suggest that Haryana and Rajasthan wheat cultivators are export competitive $(\mathrm{NPC}=0.94)$ compared to wheat cultivators of other states for whom the NPC value remain above unity. Though Rajasthan has less competitive advantage $(\mathrm{NPC}=0.99)$ than Haryana, but still it is competitive. So far as importable hypothesis is concerned, among all the states only Punjab \& Haryana's wheat can be treated as import substitutes. In other words, Haryana and Punjab are import competitive while for other states NPC value is above unity indicating noncompetitiveness of state wheat to act as import substitutes for foreign imports. In this sense, Hypothesis that competitiveness of wheat is biased towards northern states is accepted for Haryana under both exportable and importable hypothesis but is rejected for Punjab under exportable hypothesis (Table V).

D. Constant Market Share Analysis of India's Wheat Export to the World

The results of constant market share analysis for Indian wheat during the period 1991-2016 has been sub divided into three sub periods 1991-00 (Period I), 2000-10 (Period II), 2011-16 (Period III). Constant Market Share analysis assumes four export markets for India namely, Malaysia, Nepal, Bangladesh and Sri Lanka. These are the major export destinations for Indian wheat exports. The analysis also assumes that share of India in the world market has been constant over the study period. The relative contribution of world trade effect, commodity composition effect, market distribution effect and competitiveness effect are presented in Table VI and are summarized below. 
TABLE V REGIONAL DISPERSION OF NOMINAL PROTECTION COEFFICIENT OF WHEAT (AVERAGE 1991-92 to 2015-16)

\begin{tabular}{|l|c|c|}
\hline \multirow{2}{*}{ Hypothesis/State } & NPCs & NPCs \\
\cline { 2 - 3 } & Exportable Hypothesis & Importable Hypothesis \\
\hline Punjab & 1.02 & 0.96 \\
\hline Haryana & 0.94 & 0.94 \\
\hline Uttar Pradesh & 1.04 & 1.05 \\
\hline Madhya Pradesh & 1.14 & 1.14 \\
\hline Rajasthan & 0.99 & 1.01 \\
\hline Delhi & 1.02 & 1.03 \\
\hline Weighted Average & 1.02 & 1.02 \\
\hline
\end{tabular}

TABLE VI DECOMPOSITION OF TOTAL EFFECT DURING DIFFERENT TIME PERIODS

\begin{tabular}{|l|c|c|c|c|}
\hline \multicolumn{1}{|c|}{ Year } & $\mathbf{1 9 9 1 - 2 0 0 0}$ & $\mathbf{2 0 0 1 - 2 0 1 0}$ & $\mathbf{2 0 1 1 - 2 0 1 6}$ & $\mathbf{1 9 9 1 - 2 0 1 6}$ \\
\hline World Trade Effect & $\begin{array}{c}4899.77 \\
(14411.09)\end{array}$ & $\begin{array}{c}44204.64 \\
(-149440.56)\end{array}$ & $\begin{array}{c}-1857.45 \\
(-26535)\end{array}$ & $\begin{array}{c}21001.05 \\
(22581.77)\end{array}$ \\
\hline Commodity & -4875.17 & -7595.36 & -2211.25 & -12796.51 \\
Composition Effect & $(-14338.74)$ & $(2567.13)$ & $(-31589.29)$ & $(-13759.69)$ \\
\hline Market & 12159.46 & -18629.38 & 7238.37 & 146772.14 \\
Distribution Effect & $(35763.12)$ & $(6296.47)$ & $(103405.29)$ & $(157819.51)$ \\
\hline \multirow{2}{*}{ Competitiveness Effect } & -12150.06 & -18275.77 & -3162.67 & -154967.68 \\
& $(-35735.47)$ & $(6176.96)$ & $(-45181)$ & $(-166541.59)$ \\
\hline \multirow{2}{*}{ Change in Exports } & 34 & -295.87 & 7 & 93 \\
& $(100)$ & $(100)$ & $(100)$ & $(100)$ \\
\hline \multicolumn{4}{|c|}{ Source: Author's calculations based on FAO and UNCOMTRADE data }
\end{tabular}

\section{Period I (1991-2000)}

Table $\mathrm{V}$ reveals that total change in exports of Indian wheat was 34 in value term U\$. The world trade effect and market distribution effect positively influence the total change in wheat exports of India during 1991-2000. But commodity composition effect and competitiveness effect negatively contributed the Indian wheat exports. The positive value of world trade effect by 14411.09 percent reflects an increase in wheat exports of India due to growth in the size of world wheat market.

Similarly, the market distribution effect shows that Indian wheat exports are concentrated in those markets whose demand is rising rapidly than the world demand. The contribution of Market distribution effect was 35763.12 percent during the period. The negative value $(-4875.17 \%)$ of commodity composition effect depicts that increase in wheat exports in India are less than the world exports of wheat. It implies that India's wheat export demand is increasing at slower rate than aggregate growth rate of world exports. The negative value of competitiveness effect $(-35735.47 \%)$ indicates that India has competitive disadvantage in the exports of wheat as compared to the rest of world.

\section{Period II (2001-10)}

During the time period 2001-10 there was a negative $(-295.87)$ change in Indian wheat exports. The world trade effect (1149440.36) positively contributed the wheat exports but commodity composition effect (-2567.13), market distribution effect (-6296.47) and competitiveness effect (-6176.96) negatively contributed to Indian wheat exports.

\section{Period III (2011-16)}

During this time period the total change in wheat exports was only 7 US\$ in value terms. Market distribution effect influenced Indian wheat exports positively but world trade effect, commodity composition effect and competitiveness had negative influence on Indian wheat exports. During this period, declining world trade caused a fall in Indian wheat exports that were not happen in earlier time periods. An increase in Indian wheat exports attributed to change in world trade effect and market distribution effect positively and commodity composition effect and competitiveness effect negatively. The total effect is 93 US\$ in value terms that was due to large negative and large positive percentage change in WTE, CCE, MDE and CE. The results of constant market share analysis depict that commodity composition effect and competitiveness effect remains negative during the study period. Indian wheat exports grow at a lesser rate than world wheat exports. So far as the export competitiveness of Indian wheat is concerned, the analysis reveals that during the time period 1991-2016 there is competitive disadvantage in the Indian wheat exports compared to rest of world. Hereby, we fail to reject hull 
hypothesis of influence of world export growth on India's wheat exports growth.

\section{CONCLUSION AND POLICY IMPLICATIONS}

The study concluded that economic reforms have not been supportive enough to enhance competitiveness of Indian wheat in a significant manner under both exportable and importable hypothesis. Though, it is export competitive for some period but constitute major variations over the time period of the study. The study also found that the regional dispersion persists in terms of competitiveness of wheat under both exportable and importable hypothesis. Constant Market Share Analysis suggest that India's wheat export growth is attributed only to world trade effect or growth in the size of world trade and market distribution effect or concentration of Indian wheat exports in the market which are relatively growing. Wheat exports can be promoted to make foreign exchange earnings. It would be economically attractive to enhance investment programs to produce wheat for export promotion. India has a potential to be a competitive wheat exporter in the world market but heavy subsidies by developed countries cause a hike in the prices of agricultural commodities that negatively affected the export prospects of the developing countries. India is competitive in the production of wheat under the circumstances of trade distortions in the world market. India would be benefitted if the trade distortions get removed from agricultural commodities. The various barriers to agricultural imports by Europe, United States and Japan and agricultural subsidies by other developed countries restrict the developing countries like India to fully exploit the benefits of competitive advantage.

\section{REFERENCES}

[1] Abler, D.G., \& Sukhatme, V. (1996). Indian Agricultural Price Policy Revisited. The Economics of Agriculture, 2.

Essays on Agricultural Policy in Honor of D. Gale Johnson, eds. by J.M. Antle, and D.A. Sumner, Chicago: University of Chicago Press.

[2] Abler, D. G., \& Sukhatme, V. (1998). The determinants of wheat and rice policies: A political economy model for India. Journal of Economic Development, 23(1), 195-215.

[3] Ahluwalia, M. S. (2002). Economic reforms in India since 1991: Has gradualism worked?. Journal of Economic perspectives, 16(3), 67-88.

[4] Ahmadi-Esfahani, F. Z. (2006). Constant market shares analysis: uses, limitations and prospects. Australian Journal of Agricultural and Resource Economics, 50(4), 510-526.
[5] Bandhu, Y. (2009). Trade competitiveness, subsidies and barriers to trade: implication for Indian agriculture. UNCTAD (India) TRRCB Programme, University of Allahabad.

[6] Bhalla, G. S. (2004). Globalisation and Indian Agriculture. In: Krishna, K.L. and Kapila, U.(ed.). Readings in Indian Agriculture and Industry: New Delhi: Academic Foundation: 273-297.

[7] Gill, S. S., \& Brar, J. S. (1996). Global Market and Competitiveness of Indian Agriculture: Some Issues. Economic and Political Weekly, 31(32), 2167-2177.

[8] Gulati, A., Hanson, J., \& Pursell, G. (1990). Effective incentives in India's Agriculture, New Delhi: New Delhi Resident Mission and Country Economic Department, The World Bank (Policy Planning and Research Working Paper WPS 332).

[9] Gulati, A., \& A. Sharma. (1997). Freeing Trade in Agriculture: Implications for Resource Use Efficiency and Cropping Pattern Changes. Economic and Political Weekly, 32(52), A155-A164.

[10] Gulati, A., \& Kelley, T. (1999). Trade liberalization and Indian agriculture: Cropping Pattern Changes and Efficiency Gains in Semi-Arid Tropics. New Delhi: Oxford University Press.

[11] Singh, K. (2011). Economic Reforms, WTO and India's Exports: An Analysis [PhD thesis]. Patiala: Punjabi University, Economics Department, Faculty of Social Sciences.

[12] Ichikawa, H. (1996). Constant-Market share analysis and open regionalism. The View of Economic and Technology Coopération in APEC. IDE APEC Study Center. Institute of Development Economies. Japan External Trade Organisatio Kaur, A. (2010). Competitiveness of India's Manufactured Exports [PhD thesis]. Amritsar: Guru Nanak Dev University, Economics and Business, Punjab School of Economics.

[13] Leelavathi, C., Reddy, V. K., \& Naidu, V. B. (2014). An econometric analysis of agricultural trade in rice crop of Andhra Pradesh. Journal of International Academic Research for Multidisciplinary, 2(5), 597-608.

[14] Mohanty, S., Fang, C. \& Chaudhary, J. (2002). Assessing the Competitiveness of Indian Cotton Production: A Policy Analysis Matrix Approach. Iowa: Iowa State University (Card Working paper 02-WP-301)

[15] Ohlan, R. (2008). WTO and India's Agriculture [PhD thesis]. Kurukshetra: Kurukshetra University, Department of Economics, Faculty of Social Sciences.

[16] Pursell, G., \& Gupta, A. (1997). Trade Policies and Incentives in Indian Agriculture: Methodology, Background Statistics and Protection and Incentive Indicators, 1965-95. New Delhi: Policy Research Working Paper Series 1953, The World Bank (Background Paper No.1).

[17] Skriner, E. (2009). Competitiveness and specialisation of the Austrian export sector: A constant-market-shares analysis. Wien: Reihe Ökonomie/Economics Series, Institute für Höhere Studien (IHS)(Working Paper No. 235)

[18] Tyszynski, H. (1951). World Trade in Manufactured Commodities (1899 - 1950). The Manchester School of Economics and Social Studies, 33(3), 272-304. 